\title{
Hva motiverer deg til å fortsette som kursleder i Vivat?
}

Innspill fra Hanna Guro Brekke

\section{Undervisningsprogrammet $\mathbf{V} \mathbf{V} \mathbf{a} \mathbf{t}$}

$M$ in umiddel bare tanke når jeg får dette spørsmålet, er den positive opplevelsen jeg sitter igjen med hver gang jeg har gj ennomført et Vivat-kurs, sier H anna $\mathrm{G}$ uro B rekke. Etter to intense og travle dager, og når jeg egentlig er ganske sliten, så kjenner jeg: Ja, dette er gøy, dette funker! O g i stedet for å kjenne meg tappet for energi, har møte med engasjerte kursdeltagere gitt meg fornyet inspirasjon til å fortsette som kursleder. I mitt daglige arbeid som psykiatrisk sykepleier møter jeg mennesker med mange forkjellige psykiske vansker, og jeg har en travel og utfordrende hverdag. D et tar tid og krefter å sette seg ned etter arbeidstid å forberede seg til et nytt Vivat-kurs, men min erfaring er at det er verdt det.

\section{Hva er det som er unikt med Vivats førstehjelpskurs ved selvmordsfare?}

Jeg er utdannet psykiatrisk sykepleier og gruppeterapeut, og har selv deltatt på flere kursi forhold til selvmordsproblematikken. $\mathrm{N}$ oen av dem har gitt meg nyttig kunnskap, og ofte har fokus vært på behandling av selvmorstruede pasienter over tid. Vivat-kurset er et førstehjelpskurs, med fokus på å oppdage, vurdere risiko og kunne intervenere ved akutt selvmordsfare. En del av våre kursdeltagere, som f.eks. fagpersoner fra psykiatrien, har lang erfaring med behandling av selv mordstruede personer. $M$ en på samme måte som helsepersonell trenger å holde seg oppdatert i forhold til førstehjelp ved fysiske skader og ulykker, er et kurs i førstehjelp ved selvmordsfare nyttig.

Fagutviklingsenheten ved Psykiatrien i Vestfold (helseforetak) arrangerer hvert år Vivat-kurs, og inviterer da både helsepersonell fra første- og andrelinjetjenesten og ansatte i skolen, politiet, barneverntjenesten, kirken og frivillige organisasjoner. Dette gjør at alle disse får en felles kunnskap, og kurset blir også en møteplass med muligheter for fremtidig samarbeid. Her i Vestfold har Kirkens SOS hatt Vivatkurset som et tilbud til alle nye frivillige hjelpere. Dette er mennesker med mange forskjellige yrker og med ulik erfaringsbakgrunn.

$M$ in erfaring er at det er en styrke å ha en tverrfaglig gruppe del tagere på kursene, det ideelle er en gruppe sammensatt av både profesjonelle hjelpere, og frivillige. A ntallet kursdeltagere kan ikke være for stort, da mye av undervisningen foregår i små grupper. Kurset legger vekt på at alle deltagerne bidrar aktivt med sine erfaringer og sin kunnskap, og ønsker å bevisstgjøre del tagerne på hvilke ressurser de har i nærmiljøet. Kurset blir derfor også litt forskjellig fra gang til gang, og det gjør at det aldri blir kjedelig å være Vivatkursleder. Jeg opplever at jeg selv alltid lærer noe nytt, og at det er en spennende utfordring å lede kurset hver eneste gang.

Kurset består av flere elementer, med vekt på bevisstgjøring av egne følelser og holdninger til tema, formidlig av kunnskaper og ikke minst ferdighetstrening. Det legges også vekt på å bruke flere forskjellige undervisningsmetoder, og utfordringene deltagerne møter har en naturlig progresjon. Kursdeltagerne gir tilbakemeldinger om at kombinasjonen av teori og praktisk trening gjennom rollespill gjør dem trygge og forberedt til å kunne hjelpe sel vmordsnære personer. Treningen de får på kurset i å bruke intervensjonsmodellen, gjør at dette ikke bare blir en teoretisk modell, men et redskap som de kan bruke i hverdagen. Disse tilbakemeldingene er en viktig inspirasjon for meg som kursleder.

\section{Hvordan følger Vivat opp og leg- ger til rette for oss kursledere?}

Selv om den aller viktigste motivasjonen for å fortsette som kursl eder er gl eden over å gjøre noe som jeg ser fungerer, er oppføl gingen fra Vivat også viktig. Den startet under kurslederutdanningen, som går over en intens uke. Her møtte jeg dyktige kursledere som var engasjerte og inspirerende. For øvrig inviteres vi til landsdekkende samlinger, dette har tidligere vært en årlig foreteelse, men er nå endret til annethvert år. Vivat har en lite topptung ledelse, med en leder og en sekretær som begge har base i Tromsø. Det er veiledere på deltid i de forskjellige hel seregionene, og vi får tilbud om regionale dagssamlinger en til to ganger i året. Jeg har satt pris på både landssamlingene og de regionale samlingene. Spesielt det å møte andre kursledere, og at vi kan
Landsdekkende kurs:

Førstehjelp ved selvmordsfare

Førstehjelp ved selvmordsfare er et intensivt todagers kurs. Det retter seg mot alle som $\mathrm{i}$ sitt virke møter selvmordsnære mennesker, og er et praktisk, tverrfaglig kurs hvor deltakerne lærer å tyde faresignaler og gripe inn i tilfelle akutt selvmordsfare. Målet er at deltakerne etter kurset skal være mer kompetente og tryggere i å intervenere i akutte selvmordskriser. På kurset lærer man å:

- Fange opp mennesker som kan være i selvmordsfare

- Stille direkte spørsmål om selvmordstanker

- Hjelpe personen i selvmordsfare til å snakke om det som er vanskelig

- Gjøre en enkel risikovurdering

- Lage og iverksette en plan med vedkom mende, hvor målet er å berge livet

- Bruke nære ressurser i krisehjelp

Mer enn 10.000 personer har deltatt på Vivat-kurset i Norge siden starten i 1998. Det er på verdensbasis det mest brukte selvmordsforebyggende kurset. Kurset er godkjent av flere fagforeninger som tellende i forbindelse med fagspesialisering.

Vivat er finansiert av Sosial- og helsdedirektoratet

For mer informasjon kontakt: Vivat, Universitetssykehuset Nord-Norge HF Postboks 6124, 9291 Troms $\emptyset$

www.unn.no/vivat e-post:vivat@unn.no

inspirere og lære av hverandre. Jeg blir også minnet på at jeg er en liten brikke i et stort og viktig arbeid, og er stolt av å få være en del av dette. M ye av kontakten med Vivat blir likevel over e-post, og vi sender inn kursrapporter og evalueringen fra deltagerne. Vivat er opptatt av å kvalitetssikre kursene, det er en trygghet for meg som kursleder.

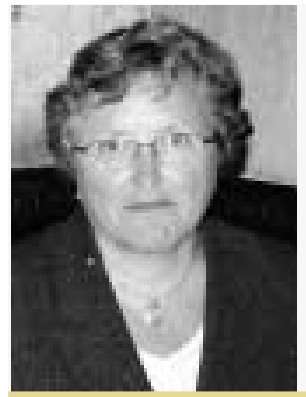

H anna G uro Brekke har kursledererfaring fra 2001 og holder Vivat-kurs for fagpersoner i første- og andrelinjetjenesten og for frivillige hjelpere. Hun er ansatt i Psykiatrien i Vestfold. 